\title{
ОСОБЛИВОСТІ ДІАГНОСТИКИ ТА ПРОГНОЗУВАННЯ ДИСГОРМОНАЛЬНИХ ЗАХВОРЮВАНЬ МОЛОЧНОЇ ЗАЛОЗИ У ЖІНОК ГРУПИ ВИСОКОГО РИЗИКУ ЗЛОЯКІСНИХ НОВОУТВОРЕНЬ
}

\author{
С. М. Геряк, В. М. Хіночик \\ ДВНз «Тернопільський державний медичний університет \\ імені І. Я. Горбачевського МОЗ Украӥни»
}

\begin{abstract}
Аналіз методик скринінгу раку молочної залози показує, що смертність серед жінок груп ризику, які взяли участь у профілактичній програмі лікування дифузних захворювань молочної залози, на 30-50 \% нижче, ніж у групах, де профілактика раку молочної залози не проводилась. У контексті сказаного визначальну роль при підозрі/виявленні злоякісних захворювань молочної залози серед жінок слід відвести регулярним медичним оглядам, зокрема цільовому та профілактичному. Завдяки цьому Рівненщина займає одне з останніх місць в Україні за кількістю хворих на рак молочної залози. Отже, немає сумнівів, що своєчасна рання діагностика, адекватне лікування і профілактика дисгормональної патології молочної залози сприяє зниженню захворюваності.
\end{abstract}

\section{DIAGNOSTIC FEATURES AND PROGNOSIS OF DISHORMONAL BREAST DISEASE FOR HIGH RISK CANCER GROUP}

\author{
S. M. Heryak, V. M. Khinochik
}

\section{Horbachevsky Ternopil State Madical University}

\begin{abstract}
Analysis methods of screening for breast cancer shows that mortality risk women who took part in the program of preventive treatment of diffuse disease at breast cancer is 30-50 \% lower than for ones without. In the context of the above crucial role for detection of malignant breast disease should be given to the regular medical examinations, including destination and prevention. Thanks to this, Rivne takes one of the last places in Ukraine by the number of patients with breast cancer. Consequently, there is no doubt that prompt early diagnosis, appropriate treatment and prevention of dishormonal breast pathology reduce morbidity.
\end{abstract}

Вступ. Архіважливим у процесі реформування функціонуючої медичної галузі $є$ вирішення доволі істинної проблеми - зміцнення та збереження здоров'я осіб працездатного віку. Поясненням цього $є$ існуючий в суспільному житті процес «старіння» населення, що призвів до його депопуляції, а саме: збільшення демоекономічного навантаження на працюючу категорію осіб, труднощів у формуванні трудового ресурсу, забезпечення народного господарства здоровою робочою силою. Особливо властивим це є для осіб жіночої статі, оскільки саме на жінку працездатного віку покладається ще тягар берегині сім'і - жінки-матері, жінки-дружини, жінки-домогосподині, жінки-менеджера, жінки-політика тощо. Особливу турботу серед осіб жіночої статі викликає рак молочної залози, що $є$ найпоширенішим онкологічним захворюванням $[8,9]$.

(c) С. М. Геряк, В. М. Хіночик, 2017
Згідно зі статистичними даними ВООЗ, щорічно у всьому світі діагностується понад мільйон нових випадків розвитку злоякісних пухлин молочних залоз. Смертність від цієї патології перевищує 50 \% всіх хворих. Зниженню цього показника перешкоджає відсутність у багатьох країнах організованого якісного профілактичного скринінгу населення для раннього виявлення злоякісних новоутворень молочних залоз. Аналіз методик скринінгу раку молочної залози показує, що смертність серед жінок груп ризику, які взяли участь у профілактичній програмі лікування дифузних захворювань молочної залози, на 30-50 \% нижче, ніж у групах, де профілактика раку молочної залози не проводилась.

Отже, немає сумнівів, що своєчасна рання діагностика, адекватне лікування і профілактика дисгормональної патології молочної залози сприяє зниженню 
захворюваності. Здійснення на практиці заходів, спрямованих на більш раннє виявлення передпухлинних захворювань і раку молочної залози, є пріоритетними ще й тому, що лікування «локалізованих» форм раку (без метастазів у лімфатичні вузли) сприяє стійкому багаторічному виліковуванню $[10,11]$.

Основна частина. На сьогодні остаточно не з'ясовані причини і пускові механізми розвитку доброякісних і злоякісних пухлин молочної залози. Проте за результатами проведення багатоцільових епідеміологічних і експериментальних досліджень виявлено ряд чинників, що підвищують ризик виникнення пухлин молочної залози $[2,6]$.

Важливими факторами ризику $\epsilon$ антропогенні - забруднення навколишнього середовища в результаті діяльності людини: забруднення повітря промисловими підприємствами, зокрема заводами, фабриками, тепловими електростанціями, транспортом, які викидають у повітря пил, сажу, різні хімічні сполуки; забруднення радіоактивними речовинами; забруднення води, основними джерелами якої є промислові підприємства, що скидають у річки і водойми неочищені стоки, а також змитими з полів мінеральними добривами та отрутохімікатами; забруднення ґрунту шляхом нагромадження іонів важких металів $[1,3,5]$. Надмірне використання отрутохімікатів та мінеральних добрив. Забруднення радіоактивними речовинами.

Значна роль належить і чинникам соціального середовища: зниження народжуваності та зростання смертності внаслідок економічних, соціальних і психологічних чинників, міграція населення за кордон, підвищення захворюваності та поширення хвороб серед різних вікових груп населення.

Молочна залоза, що належить до органів репродуктивної системи, і $\epsilon$ органом-мішенню для стероїдних гормонів яєчників, кори надниркових залоз, пептидних гормонів гіпофіза щитоподібної залози, а також різноманітних біологічно активних сполук. Певний ритм функціонування репродуктивної системи жінки зумовлює циклічність змін у тканинах молочної залози. Серед причин, що порушують циклічність процесів у молочній залозі і $є$ провідними щодо стимуляції проліферативних процесів у ній, виділяють: ендокринні й обмінні захворювання, гінекологічні захворювання (порушення менструальної функції, запальні захворювання геніталій, міома матки, ендометріоз тощо). Зниження функціональної активності репродуктивної системи також може зумовлювати виникнення захворювань молочної залози.

До чинників ризику виникнення пухлин молочної залози і насамперед раку молочної залози належать:

- спадковість - випадки раку молочної залози у кровних родичів (у матері, сестри або дочки). У таких жінок ризик розвитку цієї патології у 2 рази вищий, ніж у інших жінок, особливо, якщо родичі хворіли на рак молочної залози в пременопаузі або рак був двостороннім; наявність кількох випадків раку молочної залози в сім'ї - принаймні в 3-х близьких родичів, і це відповідає аутосомній домінантній схемі;

- порушення репродуктивної функції, а саме: непліддя, вік при народженні першої дитини (після 30 років), відсутність пологів, пізня перша вагітність, що закінчилась викиднем (після 30 років), вік початку менструацій до 12 років, вік настання менопаузи (рання або пізня менопауза);

- вік - з віком підвищується ризик захворювання на рак молочної залози. Найбільший ризик спостерігається у віці 45-75 років із двома піками у віці 45-49 років і 70-74 роки;

- захворювання щитоподібної залози: тиреотоксикоз, гіпотиреоз;

- захворювання нервової системи: неврастенія, вегетоневрози, психічні травми та велика кількість стресів;

- проживання у місті, малорухливий спосіб життя;

- споживання їжі, що містить велику кількість жирів: червоного м'яса (свинина, яловичина, баранина);

- куріння та вживання алкоголю;

- надлишкова маса тіла після 40 років;

- існування дисгормональних гіперплазій, особливо фіброзно-кістозних захворювань молочної залози, інвазивні або неінвазивні форми раку молочної залози з проведенням біопсій з виявленням атипових гіперплазій і долькової карциноми;

- неконтрольоване приймання комбінованих гормональних контрацептивів [7, 12].

Захворюваність на рак молочної залози є проблемою майже у всіх країнах світу. Особливістю, притаманній Україні, $є$ те, що значна частина населення продовжує проживати на радіаційно забруднених теренах через аварію на ЧАЕС. Серед різновидів соматичної патології внаслідок цієї аварії привертає увагу захворюваність на злоякісні новоутворення.

Разом з тим, можна констатувати, що за даними статистики, Рівненщина займає одне з останніх місць в Україні за кількістю хворих на рак молочної залози (табл. 1). 
таблиця 1. Порівняльні дані виявлення раку молочної залози серед жіночого населення у Рівненській області за останні 5 років

\begin{tabular}{|l|c|c|c|c|c|}
\hline \multicolumn{1}{|c|}{ Показники } & 2011 p. & 2012 p. & 2013 p. & 2014 p. & 2015 p. \\
\hline Виявлено хворих (абс.) & 291 & 287 & 303 & 297 & 276 \\
\hline 3 них при профоглядах (\%) & 58,4 & 57,5 & 53,5 & 61,9 & 55,1 \\
\hline 3 них на початкових (I-ІІ) стадіях (\%) & 75,6 & 78,4 & 66,3 & 73,0 & 68,8 \\
\hline 3 них на пізніх (III-ІV) стадіях (\%) & 21,9 & 16,7 & 29,0 & 24,9 & 28,6 \\
\hline Захворюваність (на 100 тис. жін. нас.) & 48,7 & 49,2 & 51,5 & 51,7 & 47,4 \\
\hline Морфоверифікація діагнозу (\%) & 89,8 & 91,0 & 88,9 & 93,0 & 95,1 \\
\hline Охоплення спецлікуванням (\%) & 81,8 & 76,7 & 75,2 & 81,4 & 79,3 \\
\hline В т. ч. методами: - хірургічним (\%) & 20,2 & 28,6 & 22,4 & 32,6 & 21,9 \\
\hline - променевим (\%) & 8,4 & 9,5 & 7,5 & 5,4 & 4,1 \\
\hline - хіміотерапевтичним (\%) & 9,7 & 9,5 & 20,6 & 17,3 & 25,6 \\
\hline - комбінованим і комплексним (\%) & 57,1 & 47,7 & 47,8 & 43,0 & 45,7 \\
\hline - хіміопроменевим (\%) & 4,6 & 4,5 & 1,8 & 1,7 & 2,8 \\
\hline Перебувало на обліку хворих (абс.) & 2584 & 2414 & 2832 & 2933 & 3050 \\
\hline 3 них більше 5 років (\%) & 59,4 & 60,6 & 60,9 & 61,5 & 62,9 \\
\hline Дорічна летальність (\%) & 11,3 & 7,6 & 10,8 & 10,2 & 9,1 \\
\hline Смертність (на 100 тис. жін. нас.) & 24,6 & 24,7 & 25,8 & 24,9 & 25,2 \\
\hline
\end{tabular}

Жіноче населення всього по області складає 609700 осіб.

Кількість випадків захворювань на рак молочної залози у північних районах Рівненської області: 2011 р. 63 випадки; 2012 р. - 67 випадків; 2013 р. - 70 випадків; 2014 р. - 65 випадків; 2015 р. - 64 випадки [16, 17].

У медичному забезпеченні населення існують організаційні канони, коли наявність хвороби, як правило, підозрюють чи діагностують при звертанні пацієнта до лікаря/медичного закладу. Важливу роль у цьому відіграють медичні огляди (профілактичні, попередні, періодичні та цільові) як профілактичні технології, що дає змогу своєчасно виявити чи запідозрити ту чи іншу патологію. У контексті сказаного визначальну роль при підозрі/виявленні злоякісних захворювань молочної залози серед жінок слід відвести регулярним медичним оглядам, зокрема цільовому та профілактичному $[15,17,18]$.

Раннє виявлення - це найкращий захист від хвороби. Чим раніше діагностують це захворювання, тим вищі шанси на повне одужання. Для того, щоб обстежити молочну залозу в домашніх умовах і виявити новоутворення навіть невеликих розмірів достатньо так званого їі пальпаторного обстеження. Таким чином, можна виявити невеличкі ущільнення у молочній залозі. Тому важливо, щоб кожна жінка оволоділа технікою самообстеження молочних залоз.
Рак молочної залози схильний до швидкого метастазування в регіональні лімфовузли: пахвові, підключичні, парастернальні. Далі з течією лімфи ракові клітини поширюються по надключичних, лопаткових, медіастенальних та шийних вузлах, тому пальпацію лімфатичних вузлів при обстеженні необхідно проводити в обов'язковому порядку, що може зробити лише спеціаліст.

Лікування раку молочної залози - хірургічне. Вибір операції залежить від розміру пухлини, ступеня ураженості прилеглих тканин і лімфовузлів. Довгий час практично всім жінкам із виявленою злоякісною пухлиною молочної залози проводилась радикальна мастектомія (повне видалення залози, розташованих поруч лімфатичних вузлів і м'язів грудної клітки, розташованих під нею). Зараз все частіше роблять модифікований аналог операції, коли грудні м'язи зберігають (якщо вони не зачеплені злоякісним процесом) із одночасним встановленням імплантата для зменшення косметичного дефекту. Після операційного видалення злоякісної пухлини молочної залози жінки перебувають на обліку в мамолога-онколога, регулярно спостерігаються і обстежуються для виявлення рецидиву або метастазів в інші органи. Найчастіше метастази виявляють в перші 3-5 років, потім ризик розвитку нової пухлини зменшується $[4,13,14]$.

Висновки. 1. Самим надійним заходом профілактики раку молочної залози є регулярне обстеження 
жінок мамологом, контроль за станом статевої системи, щомісячне самообстеження. Всім жінкам старше 35 років необхідно робити мамографію. Частота захворювань на рак молочної залози залежить від особливостей способу життя, взаємодії з канцерогенними чинниками зовнішнього середовища, специфічними моментами побуту та внутрішнього світу людини.

2. Своєчасне виявлення патологій статевих органів, порушень гормонального балансу, обмінних

\section{СПИСОК ЛІТЕРАТУРИ}

1. Влияние техногенного загрязнения атмосферного воздуха и питьевой воды на частоту возникновения злокачественных новообразований женской репродуктивной системы / С. В. Грищенко, В. А. Шамрай, А. А. Чистяков, А. Г. Гончар // Вест. гигиены и эпидемиологии. - 2004. - Т. 8, № 1. - С. 31-36.

2. Доповідь про стан навколишнього природного середовища в Рівненській області у 2011 р. / за ред. П. Д. Колодича. - Рівне : Державне управління охорони навколишнього природного середовища в Рівненській області, 2012. - 274 с.

3. Збірник показників здоров'я населення та діяльності медичних закладів Рівненської області за 2010-2011рр. / уклад. В. І. Височанський, П. П. Алексейчук ; Рівненська обл. держ. адміністрація, управління охорони здоров'я, Рівненський обл. інформ.-аналіт. центр мед. статистики. Рівне, 2011. - 176 с.

4. Сафронникова Р. З. Профилактика и ранняя диагностика гинекологического рака / Р. 3. Сафронникова. Минск : Тонпик, 2004. - 253 с.

5. Статистичний щорічник Рівненської області за 2011 рік / Головне управління статистики у Рівненській області. - Рівне, 2012. - 520 с.

6. Аналіз розвитку трудоресурсної ситуації в Україні [Електронний ресурс]. - Режим доступу : http://www.niss. gov.ua/Monitor/ august08/20.htm.

7. Використання досягнень популяційної генетики в профілактичній медицині / А. М. Сердюк, О. І. Тимченко, В. В. Єлагін [та ін.] // Довкілля та здоров'я. - 2001. № 2 (17). - C. 49-51.

8. Державна програма «Репродуктивне здоров'я нації» на період до 2015 року, затверджена постановою Кабінету Міністрів України від 27.12.2006 р. № 1849 [Електронний документ]. - Режим доступу : http://zakon. nau.ua/doc/? code $=1849820068 \%$ EF. захворювань, уникнення дії канцерогенних чинників сприяють зниженню ризику виникнення раку молочних залоз.

3. Своєчасне лікування, у тому числі хірургічне, раку молочної залози дає високу ефективність - від раку молочних залоз виліковуються 95 \% жінок, у яких захворювання виявлено на першій стадії, 80 \% жінок, у яких виявлено другу стадію, і лише 50 \% жінок із третьою стадією захворювання.

9. Концепция эпидемиологического перехода [Электронный ресурс]. - Режим доступа : http:// ru.wikipedia.org/wiki

10. Налескіна П. А. Сучасні класифікації солідних пухлин [Електронний ресурс] / П. А. Налескіна // Doctor. 2003. - № 4 - Режим доступу : http://www.cancer.ic.ck. ua/u_index_2_8.htm.

11. Омран А. Эпидемиологический аспект теории естественного движения населения / А. Омран // О демографических проблемах в странах Запада. - М. : Прогресс, 1977. - С. 57-91.

12. Рудень В. В. Про кризовий стан у здоров'і населення «країни з ринковими перетвореннями» / В. В. Рудень, Т. Г. Гутор, О. М. Сидорчук // Охорона здоров'я України. 2006. - № 3-4 (22-23). - С. 52-59.

13. Сердюк А. М. Профілактична медицина: стан та перспективи розвитку профілактики вродженої і спадкової патології у новонароджених / А. М. Сердюк, О. І. Тимченко, Н. Г. Гойда // Вісник соц. гігієни та орг. охорони здоров'я України. - 2001. - № 4. - С. 11-17.

14. Смоланка І. І. Сучасний погляд на проблему діагностики і лікування раку молочної залози / І. І. Смоланка, С. Ю. Скляр // Жіночий лікар. - 2008. - № 5. - С. 8.

15. Стадії розвитку злоякісних пухлин [Електронний ресурс]. - Режим доступу : http://www.cancer.ic.ck.ua/ u_index_2_2.htm.

16. Статистична інформація державного комітету статистики України: демографічна ситуація. Населення (на початок 1990-2010рр.) [Електронний ресурс]. - Режим доступу : http://www.ukrstat.gov.ua/

17. Український канцерреєстр [Електронний ресурс]. Режим доступу : http://users.iptelecom.net.ua/ ucr/.

18. Mann H. B. On a test of whether one of two random variables is stochastically larger than the other / H. B. Mann, D. R. Whitney // Annals of Mathematical Statistics. 1947. - № 18. - P. 50-60. 